DOI: https://doi.org/10.34069/AI/2021.47.11.2

How to Cite:

Vaganova, O.I., Zheltukhina, M.R., Sinina, A.I., Tsarapkina, J.M., \& Kokoulina, O.P. (2021). Electronic gaming technologies in professional education. Amazonia Investiga, 10(47), 19-26. https://doi.org/10.34069/AI/2021.47.11.2

\title{
Electronic gaming technologies in professional education
}

\section{ЭЛЕКТРОННЫЕ ИГРОВЫЕ ТЕХНОЛОГИИ В ПРОФЕССИОНАЛЬНОМ ОБРАЗОВАНИИ}

Accepted: November 20, 2021

Written by:

Olga I. Vaganova ${ }^{4}$

https://orcid.org/0000-0001-8347-484X

Marina R. Zheltukhina ${ }^{5}$

https://orcid.org/0000-0001-7680-4003

Anna I. Sinina ${ }^{6}$

https://orcid.org/0000-0002-9484-9675

Julia M. Tsarapkina ${ }^{7}$

https://orcid.org/0000-0002-3807-4211

Olga P. Kokoulina ${ }^{8}$

https://orcid.org/0000-0001-7495-9511

\begin{abstract}
Purpose of the article: analysis of the experience of implementing electronic gaming technologies in professional education. Methodology: an increase in the use of innovative electronic tools (in percentage) over a five-year period was revealed, a survey was conducted, which made it possible to establish the influence of electronic gaming technologies on the formation of digital and professional competencies of students of higher educational institutions. Results: electronic gaming technologies and digital tools used in the process of vocational training expand the opportunities for training competitive specialists.
\end{abstract}

Key Words: electronic gaming technologies, digital competencies, vocational education, higher education institution, competencies.

\begin{abstract}
Аннотация
Цель статьи: анализ опыта реализации электронных игровых технологий в профессиональном образовании. Методология: выявлен прирост использования инновационных электронных инструментов (в процентном соотношении) за пятилетний период, проведен опрос, позволивший установить влияние электронных игровых технологий на формирование цифровой и профессиональной компетентностей студентов высших учебных заведений. Результаты: электронные игровые технологии и цифровые инструменты, используемые в процессе профессионального обучения расширяют возможности подготовки конкурентоспособных специалистов.
\end{abstract}

Ключевые слова: электронные игровые технологии, цифровая компетентность, профессиональное образование, высшее учебное заведение, компетенции.

social structures and the active introduction of

digital products into society, the requirements of
With the development of scientific and technological progress, the transformation of

\footnotetext{
${ }^{4}$ Minin Nizhny Novgorod State Pedagogical University, Nizhny Novgorod, Russia.

${ }^{5}$ Volgograd State Socio-Pedagogical University, Volgograd, Russia.

${ }^{6}$ Humanities and socio-economic disciplines department Russian State University of Justice, Saint-Petersburg, Russia.

${ }^{7}$ Russian State Agrarian University - Moscow Timiryazev Agricultural Academy, Moscow, Russia.

${ }^{8}$ Plekhanov Russian University of Economics, Moscow, Russia.
} 
the labor market for specialists have changed. They identified the need for employees with knowledge in the field of information and communication technologies as the basis for the implementation of professional activities. (Tsarapkina et al., 2021). Digital competence in professional education has taken one of the most important places. Innovative technologies are a tool that allows you to improve the quality of training and, as a result, the competitiveness of graduates.

In addition, one of the most important tasks of vocational education is to create a practiceoriented environment for the formation of professional competencies of students (Rudenko et al., 2021). The practice-oriented orientation of training contributes to the best adaptation of students to future professional activities (Vaganova et al., 2019).

To date, for the formation of professional competencies, universities use electronic gaming technologies that have emerged as a result of the development of the distance education process and electronic technologies (Yarygin et al., 2019a), which make the learning process more modern and at the same time more practiceoriented (Shashlo et al., 2018).

Electronic gaming technologies provide the student with an advantage in the form of the opportunity to acquire digital competence (Aniskin et al., 2020).

The implementation of electronic gaming technologies allows students to master digital devices, communication applications, and networks for accessing and managing information (Ivanova \& Korostelev, 2019). Students develop an individual ability to combine and use their skills related to three related areas of competence: technology, as well as cognitive and social spheres, while using the capabilities of information and communication technologies to analyze and select information relevant to a particular topic (Braslavska \& Rozhi, 2020).

Digital competence, which is formed in the process of implementing gaming technologies, contributes to the formation of competent competitive specialists in demand in the modern labor market (Pinkovetskaia et al., 2020).

Regular monitoring of the educational process is required for the implementation of high-quality organization of training using electronic gaming technologies.

\section{Theoretical framework}

The organization of educational activities with the use of information technologies, technical means and information and telecommunications networks ensures effective interaction between students and teachers, allows you to make the process the most practice-oriented and involve each student in active activities (Ponachugin \& Lapygin, 2019).

Many tools are used to implement electronic gaming technologies. Google Jamboard is an innovative tool in the implementation of electronic gaming technologies (Misakov et al., 2019). It is an interactive whiteboard that allows students to discuss emerging project ideas together, brainstorm, and record notes and solutions (Pichugina et al., 2019). Jamboard is convenient for remote work on a project because it can be used both on a computer and on a smartphone (Vaganova et al., 2020).

Among the features of working with Google Jamboard are:

- implementation of joint work (Demidov \& Tretyakov, 2016a);

- $\quad$ ability to track changes in real time;

- supports a graphics tablet (Demidov \& Tretyakov, 2016a);

- saves slides and exports the document to PDF format.

Google Docs is the most popular tool used in the professional activities of most businesses. Therefore, working with such a tool is important for the future specialist (Kharytonov et al., 2019).

Google Docs has the functionality you need to implement:

- Creating and editing documents (Kiseleva et al., 2019);

- the ability to work without the Internet;

- the ability to comment on a particular project;

- automatic document saving (Bulaeva, et al., 2018).

Kanban boards are becoming a popular tool in professional education. Kanban boards are an agile project management tool. The components of the boards are:

- the presence of visible signals (stickers, sheets on which records of all projects and work tasks appear. The signals show what 


\section{AMAZOND周 \\ 1ึvestiำ}

issue the team is working on) (Kidina, 2020);

- columns that represent specific actions that make up a complete workflow ("to be done", "in progress", " completed»);

- commitment point, where project participants choose a particular idea;

Table 1.

Electronic platforms used in the game educational process (Own authorship)

\begin{tabular}{ll}
\hline Synchronous learning & Asynchronous learning \\
\hline \multirow{2}{*}{ Zoom } & LMS : \\
& Moodle, \\
& Blackboard, \\
\multirow{2}{*}{ Skype } & iSpring \\
& Platforms with massive open online courses: \\
& Coursera, \\
Vebinar & edX, \\
& Lectorium \\
& Video hosting: \\
& YouTube, \\
\hline
\end{tabular}

The electronic platforms involved expand the possibilities of gaming activities within the framework of the implementation of projects.

\section{Methodology}

The study involved respondents selected from the number of students of higher educational institutions in the number of 324 people (Minin Nizhny Novgorod State Pedagogical University, Volgograd State Socio-Pedagogical University, Russian State University of Justice, Russian State Agrarian University, Plekhanov Russian University of Economics).

The survey for the study included 25 statements that students were required to agree with or refute. To conduct the study, the "Likert Scale" method was used, which allows you to assess the degree of consent or disagreement of the respondent on a scale from "completely agree" to "completely disagree".

Statistical analysis of the data obtained during the survey revealed the importance of electronic gaming technologies in the formation of digital competence and professional competence of students.
The dynamics of the use of electronic technologies in the educational process, the increase in the use of innovative electronic tools (in percentage terms) were revealed (Zhuk, 2011).

Descriptive analysis was involved in the work. For group descriptive statistics, characteristics such as mean and standard deviation were calculated. Descriptive analysis revealed the absolute frequency of responses, relative and cumulative. The variables were tested for normal distribution using the Shapiro-Wilk test.

\section{Results and discussion}

In the process of using electronic gaming technologies, students learn to make decisions based on available data (data-driven). Datadriven solutions are developed based on the following elements: data collection, storage in a convenient form, formulation of the right questions, analysis (why? and what to do next?).

The decision is made according to the following scheme. 


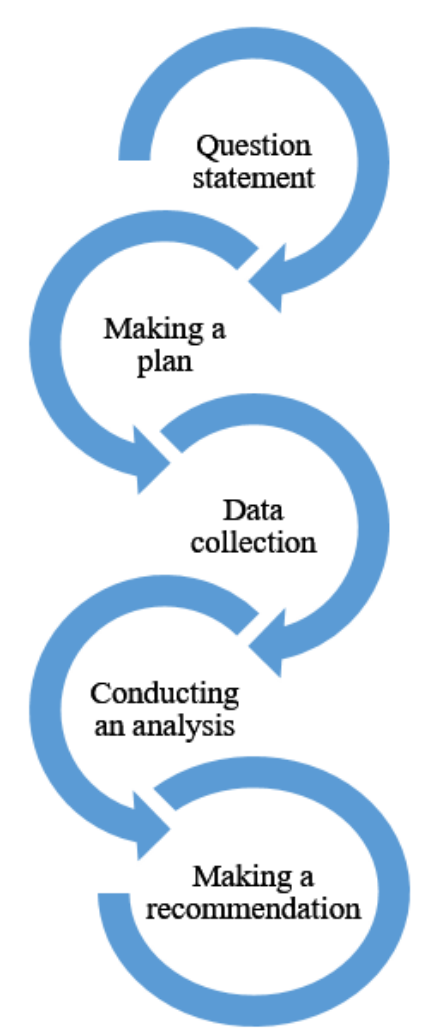

Fig. 1. Decision-making stages (Own authorship)

In the process of implementing electronic gaming technologies, the format of classes becomes practical. Problem-based learning is used, which contributes to the development of communication skills, critical thinking, and skills for quickly solving professional problems in conditions of uncertainty (Shcerbakova \& Shcerbakova, 2019). Key points in the implementation of problem-based learning: the task (problem) motivates the student to find a solution; the student argues for his answer; the problem to be solved is related to the previous topics of the discipline being studied; involvement of students in solving the problem through its gradual service.

The training uses learning by continuous doing. The end-to-end case (end-to-end business game) covers several related educational disciplines studied by students and allows them to participate in solving problems that are close to real professional conditions (Nagovitsyn et al., 2020).

Learning by continuous collaboration allows students to effectively solve collective tasks, develop communication skills, prevent and overcome conflicts to achieve joint goals.

Learning by continuous testing involves conducting tests before, during, and after the game. So the teacher can control and direct the game actions, correct the work of students on time.

Various electronic tools are used to conduct classes. Jamboard is used for student collaboration (Dobudko et al., 2019). Students fix their ideas on it and tell all the participants about them during the lesson. To point to a particular element, a laser pointer is used, which is included in the tools of the interactive whiteboard used. Students work in pairs and small groups.

The classes also use the capabilities of Google Docs. Students process the information for their projects within a Google document, as this way each participant can add and edit the text of a single document. At the same time, the teacher leaves his comments, so the advisory support is carried out quite quickly.

Kanban board allows you to manage projects remotely, increases visibility, limits the amount of work in progress. According to the special cards on the board, each participant understands exactly what tasks he should perform today. Everyone is responsible for a specific area of the overall project (and students can change functions), so the work becomes more productive. 


\section{AMAZONDA \\ 1nvestiga}

These applications and programs are not exhaustive. The figure shows the most popular skills in the professional environment that a competitive specialist should possess (according to the research report "Research of the competencies of economic Agents and Analysis of their impact on digital information", MLEA HSE, 2019) (Abdrakhmanova et al., 2019).

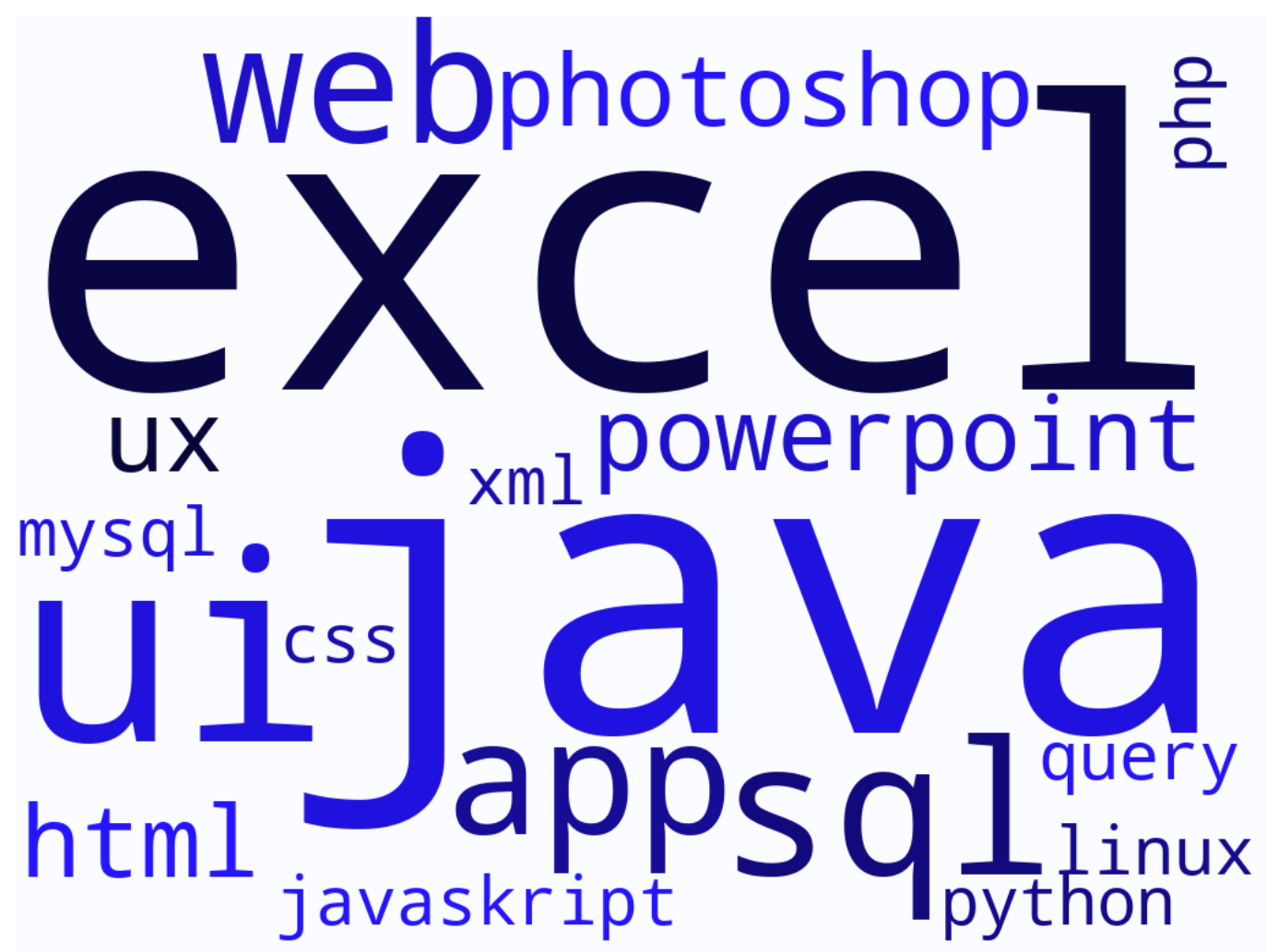

Fig. 2. The necessary skills of a competitive specialist in a modern professional environment.

In the learning process, Excel is used, which allows you to quickly work with tables and a large amount of data. Photoshop allows you to visualize some of the planned results of the work. Some programming languages are also used in the training, knowledge of the basics of which may be useful for students in their future professional activities.

A survey was conducted among students of higher educational institutions, the components of which revealed the influence of electronic gaming technologies on the formation of digital and professional competencies.

The survey included 25 questions, including: do you agree with the statements: "I feel comfortable doing tasks in the process of implementing electronic gaming technologies"; "I would like to use the digital tools introduced in training permanently" The implementation of electronic gaming technologies contributes to better mastering of the material"; "I have become better oriented in the use of programs and applications in the learning process". 


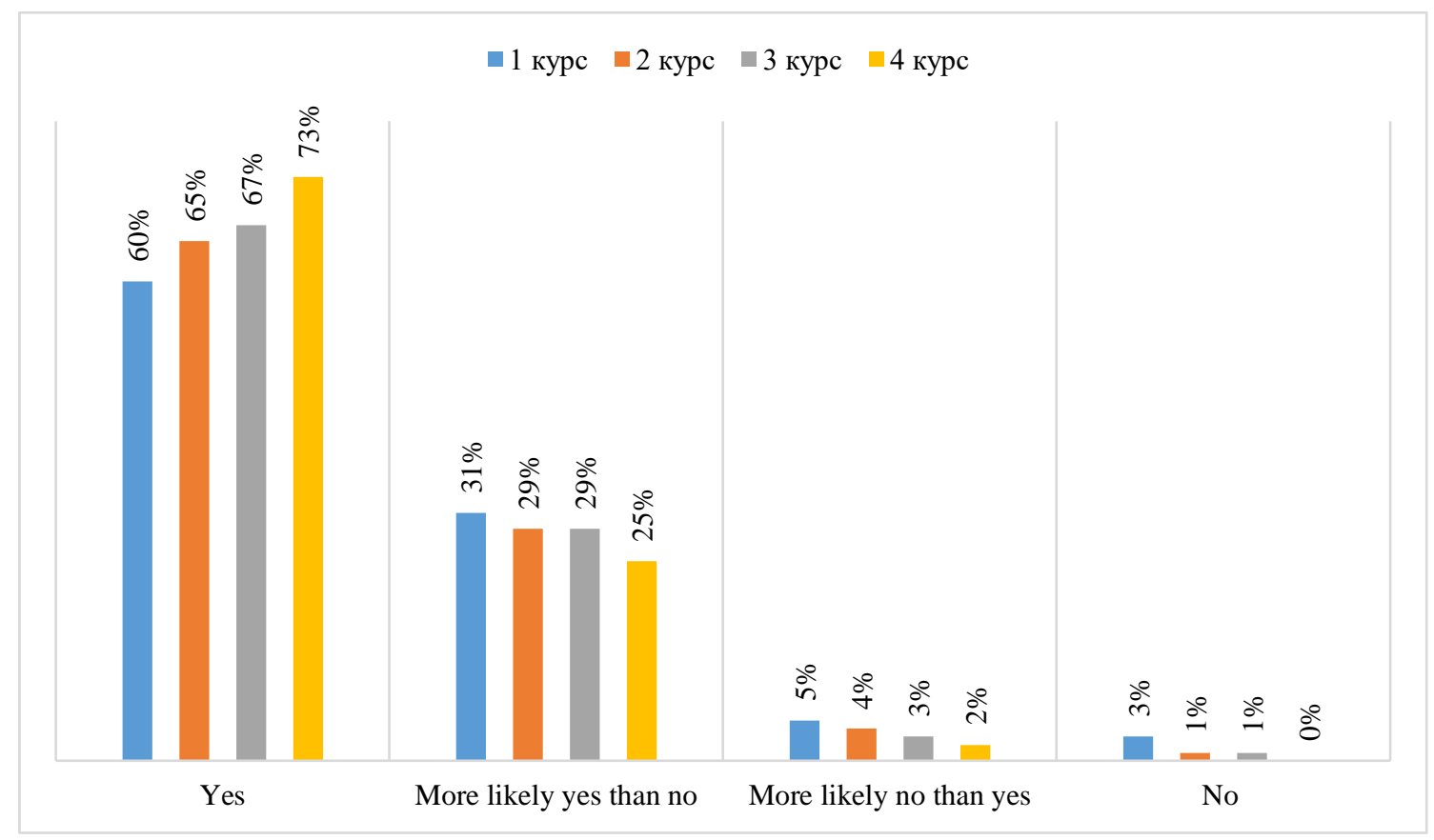

Fig. 3. Results of the survey "The impact of electronic gaming technologies on the formation of digital and professional competencies" (2020) (Own authorship)

The results allow us to establish that the majority of students, regardless of age category, note the positive impact of electronic gaming technologies on their learning. The formation of digital and professional competence in the process of implementing game technologies is more active, students are involved in practiceoriented activities.

We have identified the dynamics of the use of electronic technologies in the educational process. The figure shows an increase in the use of innovative electronic tools (as a percentage).

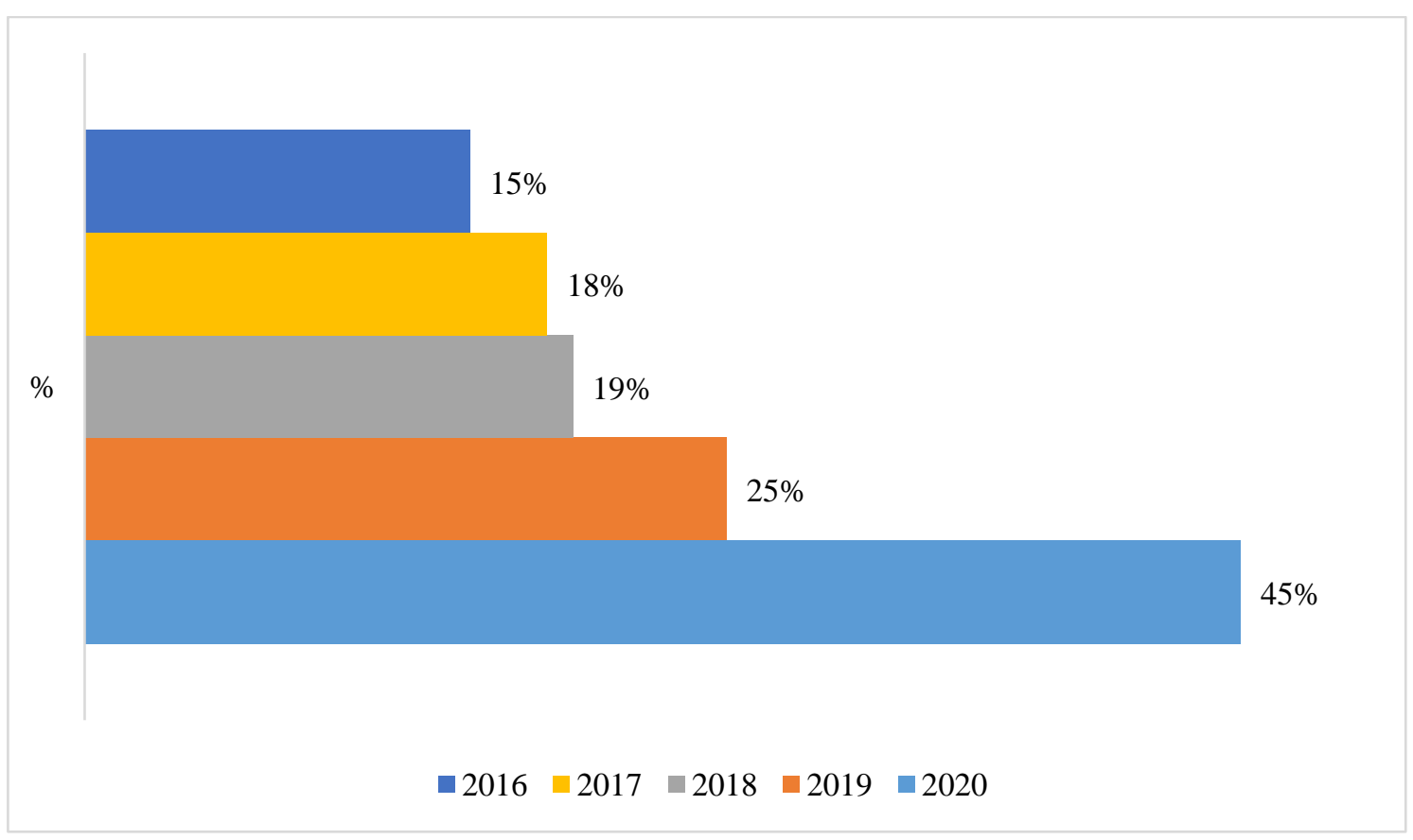

Fig. 4. Results of the assessment of the increase in the use of innovative electronic tools for 5 years (Own authorship) 


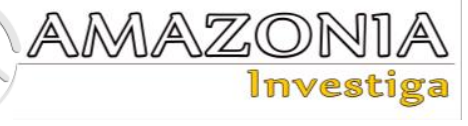

There is a leap in the use of electronic technologies for organizing interaction in 2020. This phenomenon is explained by the suddenly forced transition to the use of distance learning technologies in connection with the need to maintain social distance in the context of the pandemic.

The introduction of electronic gaming technologies has shown its effectiveness, so their use and development is a promising direction.

\section{Conclusions}

Electronic gaming technologies in modern professional education contribute to the formation of a competent specialist, form his digital competence, which today is an integral part of professional activity.

Students evaluate the programs and applications used quite highly and actively use them in the learning process, both individually and for joint activities.

Electronic gaming technologies make it possible to make the educational process more practiceoriented, as a result of which students actively participate in solving problems that are closely related to their professional activities.

\section{Bibliographic references}

Aleshchanova, I.V., Frolova, N.A., Morozova, E.V., \& Zheltukhina, M.R. (2017). Psychological and Acmeological Aspect of Educational Cognitive Competence Development. Proceedings of the 7th International Scientific and Practical Conference Current Issues of Linguistics and Didactics: The Interdisciplinary Approach in Humanities (CILDIAH 2017). Advances in Social Science, Education and Humanities Research (ASSEHR), volume 97, 19-24.

Aniskin, V. N., Korostelev, A. A., Lvovna, B. A., Kurochkin, A. V., \& Sobakina, T. G. (2020). Teaching potential of integrated learning technologies Smart, Stem and Steam. Revista De La Universidad Del Zulia, 11(29), 328-336.

Abdrakhmanova, G.I., Vishnevskiy, K.O., Gokhberg, L.M., Dranev, YU.YA., Zinina, T.S., Kovaleva, G.G., Lavrinenko, A.S., Mil'shina, YU.V., Nazarenko, A.A., Rudnik, P.B., Sokolov, A.V., Suslov, A.B., Tokareva, M.S., Turovets, YU.V., Filatova, D.A., Chernogortseva, S.V., \& Shmatko, N.A. (2019). What is the digital economy? Trends, competencies, measurement. National

Research University Higher School of Economics, Publishing House of the Higher School of Economics: report to the XX April International Scientific Conference on Development Issues (April 9-12, 2019, Moscow), 80, 45-65.

Bulaeva, M. N., Vaganova, O. I; Koldina, M. I., Lapshova, A. V., \& Khizhnyi, A.V. (2018). Preparation of Bachelors of Professional Training Using MOODLE. Advances in intelligent systems and computing, 622, pp. 406-411.

Braslavska, O. V., \& Rozhi, I. G. (2020). Peculiarities of innovative learning in a modern educational environment. Balkan Scientific Review, 4, 2(8), 24-26.

Dobudko, T.V., Korostelev, A.A., Gorbatov, S.V., Kurochkin, A.V., \& Akhmetov, L.G. (2019). The organization of the university educational process in terms of digitalization of education. Humanities and Social Sciences Reviews, 7(4), pp. 1148-1154.

Demidov, A.A. \& Tretyakov, A.L. (2016a). A network model of centers for ethical and legal education and civil-patriotic education and media education centers based on school libraries: the need to create, opportunities and real prospects, Media Education (Mediaobrazovanie), 3, pp. 16-22.

Ivanova, N., \& Korostelev, A. (2019). The impact of competitive approach on students' motivation in sport. Amazonia Investiga, 8(18), 483-490. Retrieved from https://amazoniainvestiga.info/index.php/am azonia/article/view/362

Kidina, 1. M. (2020). Management of the pedagogical collective in the conditions of implementing distance learning. Baltic Humanitarian Journal. (Baltic Humanitarian Journal), Vol. 9, No 4(33), pp. 93-96.

Kharytonov, E., Kharytonova, O., Tolmachevska, Y., Fasii, B., \& Tkalych, M. (2019). Information Security and Means of Its Legal Support. Amazonia Investiga, 8(19), 255-265. https://amazoniainvestiga.info/index.php/am azonia/article/view/227

Kiseleva, O., Lebedev, A., Pinkovetskaia, I., Rojas-Bahamón, M., \& Arbeláez Campillo, D. (2019). Specialization and concentration of small and medium enterprises employees: Russian data. Amazonia Investiga, 8(20), 6-15. https://amazoniainvestiga.info/index.php/am azonia/article/view/59

Misakov, V., Tsurova, L., Yandarbayeva, L., Tkhamadokova, I., \& Gapurovna, G. (2019). Certification of A Regional Economic Complex as a Highly Effective Tool for 
analysis and diagnostics of its development. Amazonia Investiga, 8(20), 451-458. https://amazoniainvestiga.info/index.php/am azonia/article/view/174

Nagovitsyn, R. S., Vaganova, O. I., Kutepov, M. M., M. L. N., Kosenovich, O. V., Moeseev, Yu. V., Vorotova, M. S., \& Osipov, A. Y. (2020). Interactive Technologies in Developing Student's Motivation in Physical Education and Sport. International Journal of Applied Exercise Physiology, 9(6), 78-85.

Pichugina, G.A., \& Bondarchuk, A.I. (2019). Structure of the training case in the organization of the educational process. Humanitarian Balkan Research, 2(4), pp. 5-7.

Pinkovetskaia, I., Berezina, N., \& Sverdlikova, E. (2020). The main reasons for the exit of entrepreneurs from business. Amazonia Investiga, 9(26), 68-73. https://amazoniainvestiga.info/index.php/am azonia/article/view/1113

Ponachugin, A.V., \& Lapygin, Yu.N. (2019). Digital Educational Resources of the University: Design, Analysis and Expertise. Vestnik of Minin University, 7(2), 5. (in Russ)

Rudenko, I. V., Bystrova, N. V., Smirnova, Zh. V., Vaganova, O. I., \& Kutepov, M. M. (2021). Modern technologies in working with gifted students. Propositos y representaciones, 9, № SI, Article number e818.

Shashlo, N., Petruk, G., \& Korostelev, A. (2018). Determinants of integration interaction among the subjects of the entrepreneurial innovation ecosystem of macro region. Amazonia Investiga, 7(13), 351-363. https://amazoniainvestiga.info/index.php/am azonia/article/view/569
Shcerbakova, E.V., \& Shcerbakova, T. N. (2019). Experience of Use of Remote Computer Technologies at The Organization of Independent Work of Students in The Conditions of a Mark and rating system. Baltic Humanitarian Journal. (Baltic Humanitarian Journal), 8(4) (29), pp. 192-195.

Tsarapkina, J. M., Plahina, L. N., Konoplyuk, N. V., Vaganova, O. I., \& Lapshova, A. V. (2021). The formation of bachelors' digital competencies at the university. Propositos y representaciones, 9, № SI, Article number e811.

Vaganova, O.I., Korostelev, A.A., Smirnova, Z.V., Abramova, N.S., \& Dolmatov, S.N. (2019). Improving teachers' professionalism through the development of creativity. International Journal of Innovative Technology and Exploring Engineering, 8(8), pp. 630-634.

Vaganova, O. I., Petrozitskaya, I. A., Snatovich, A. B., Odarich, I. N., \& Kirillova, I. K. (2020). Heuristic technologies of training in professional education. Amazonia Investiga, 9(27),

509-517. https://amazoniainvestiga.info/index.php/am azonia/article/view/1265

Yarygin, O.N., Korostelev, A.A., Akhmetov, L.G., \& Maseleno, A. (2019). Modeling of competence as a tool of goal setting for education in modern society. International Journal of Recent Technology and Engineering, 7(6), pp. 72-77.

Zhuk, O.L. (2011). Ways of forming a social and professional competence of a university graduate as a result and criterion of higher education quality. Science - education, production, economy, 16-19. 